\title{
Review: Anti-Oxidant and Anti-Aging Properties of Equol in Prostate Health (BPH)
}

\author{
Edwin D. Lephart ${ }^{1,2}$ \\ ${ }^{1}$ The Department of Physiology and Developmental Biology, Brigham Young University, Provo, USA \\ ${ }^{2}$ The Neuroscience Center, Brigham Young University, Provo, USA \\ Email: Edwin_Lephart@byu.edu
}

Received December 6, 2013; revised January 6, 2014; accepted January 12, 2014

Copyright (c) 2014 Edwin D. Lephart. This is an open access article distributed under the Creative Commons Attribution License, which permits unrestricted use, distribution, and reproduction in any medium, provided the original work is properly cited. In accordance of the Creative Commons Attribution License all Copyrights (c) 2014 are reserved for SCIRP and the owner of the intellectual property Edwin D. Lephart. All Copyright (C) 2014 are guarded by law and by SCIRP as a guardian.

\begin{abstract}
Benign prostatic hyperplasia (BPH) is the pathological cellular progression of glandular proliferation associated with aging. The primary changes in prostate disorders are mediated by the conversion of the principle androgen, testosterone, to its more potent metabolite, $5 \alpha$-dihydrotestosterone ( $5 \alpha$-DHT). However, recent evidence suggests that estrogen hormonal actions via estrogen receptor subtypes also play an important role in BPH. Current pharmaceutical options for BPH have advantages, limitations and adverse effects. Complementary and Alternative Medicine (CAM) treatments for BPH include botanicals such as polyphenols and isoflavones. Equol is a polyphenolic/isoflavonoid molecule derived from intestinal metabolism, dairy and dietary plant sources. Equol has potent anti-oxidant and anti-aging properties to decrease prostatic irritation and potentially neoplastic growth. It has the unique characteristic to bind specifically $5 \alpha$-DHT by sequestering $5 \alpha$-DHT from the androgen receptor (AR), thus decreasing androgen hormone actions to improve prostate health by acting as a selective androgen modulator (SAM). It also has affinity for estrogen related receptor gamma (ERR- $\gamma$ ) and estrogen receptor beta (ER- $\beta$ ) within the prostate that is known to improve male health via selective estrogen receptor modulatory (SERM) activities to decrease inflammation, cellular proliferation and carcinogenesis. The possible clinical efficacy of equol on the symptoms associated with BPH is presented and the reviewed findings suggest that equol may provide a well-tolerated and rapid beneficial therapy for BPH that can be used alone or in combination with current pharmaceutical therapies. The beneficial clinical efficacy of equol observed may be due to the multiple positive biological actions that are not present in current pharmaceutical treatments.
\end{abstract}

\section{KEYWORDS}

Androgens; Estrogens; Isoflavonoid; Equol; BPH; SERM; Selective Androgen Modulator (SAM)

\section{Introduction}

Benign prostatic hyperplasia (BPH) is the pathological progression of epithelial and stromal proliferation in the prostate gland and the most common benign neoplasm in American men [1]. These changes are mediated primarily by $5 \alpha$-dihydrotestosterone ( $5 \alpha$-DHT) levels within the prostate [1,2] but estrogen hormonal actions via estrogen related receptor (ERR) gamma $(\gamma)$ and estrogen receptor (ER) subtypes presumably play roles in BPH status $[3,4]$. There appears to be a linear increase in BPH incidence with increasing age in men over 60 years old $[1,2,5]$. It is estimated that almost 7 million Caucasian men in the
United States (in 2000) have BPH and nearly 8 million physician office visits were made to diagnose BPH [1]. The estimated costs of BPH (in 2000) exceeded \$1 billion and approximately 1 in 5 men with BPH had a clinical event, such as prostatectomies, within 1 year of initiating treatment for $\mathrm{BPH}[1,6]$. The symptoms of $\mathrm{BPH}$, (such as nocturia, the most common, causing poor quality of sleep), incomplete emptying, urinary hesitancy, weak stream, frequency, and urgency) can have a significant negative impact on the quality of life $[1,2,6]$. BPH and prostate cancer has been reviewed in several sources for primary care physicians [7-9]. 


\section{Androgens: $\mathrm{BPH}$}

As noted above, the primary changes in prostate disorders are mediated by the conversion of the principle androgen, testosterone, to its more potent metabolite, $5 \alpha$ DHT [1,2,7-9]. Notably, testosterone's binding affinity for androgen receptors (AR) is approximately $11 \mathrm{nM}$ while $5 \alpha$-DHT's binding affinity for AR is approximately 1 to $3.5 \mathrm{nM}[10,11]$. This suggests that $5 \alpha$-DHT's androgen hormone action is approximately 5-times greater than testosterone and explains, in part, the effects of this potent metabolite in prostate disorders. While somewhat controversial, there is evidence that testosterone levels decline with age in men and may be associated with cardiovascular and other disorders [12-16].

Conversely, there is clear evidence that the $5 \alpha$-reductase enzymes increase their expression within the prostate with age and disease states $[17,18]$. This suggests that even though testosterone levels decline with age, the conversion to $5 \alpha$-DHT increases to influence BPH activation and maintenance of cellular proliferation via the AR [17]. This concept of decreasing testosterone levels but increasing intra-prostatic expression of the $5 \alpha$-reductase enzymes with aging and the resulting enlargement of the prostate gland is shown in Figure 1. The action of androgens binding to the AR, as well as changes in the $5 \alpha$-reductase enzymes with BPH and prostate cancer have been reviewed [17-19].

\section{Estrogens and BPH}

While $5 \alpha$-DHT has potent actions within the prostate (and other tissue sites), 17 $\beta$-estradiol is the most potent sex steroid hormone in the body [20]. Estradiol has very high and almost equal affinity for estrogen receptor $\alpha$ (ER- $\alpha)$ and estrogen receptor $\beta$ (ER- $\beta)$ via competition binding studies where the $\mathrm{Kd}$ is $0.13 \mathrm{nM}$ and $0.15 \mathrm{nM}$, respectively [21]. Thus, estradiol within the prostate binds equally well both ER- $\alpha$ and ER- $\beta$.

Just as the production of prostatic $5 \alpha$-DHT increases with aging due to the increased expression of the intraglandular $5 \alpha$-reductase enzymes, there is evidence that the aromatase enzyme that converts androgens to estrogens significantly increases within adipose tissue with aging in men. For instance, in early investigations by Hemsell et al. in 1974, both women and men demonstrated that with advancing age, there is a progressive and significant increase in the efficiency (by 2- to 4-fold) with which androgens are converted to estrogens, suggesting that increased expression of the aromatase enzyme was responsible for these findings [22]. Later molecular biology studies by Bulun and Simpson in 1994 confirmed this notion and extended these findings that aromatase gene expression was greatest in the buttocks and thighs followed by the abdomen with advancing age
$5 \alpha-\mathrm{DHT}$ levels affect prostate health:

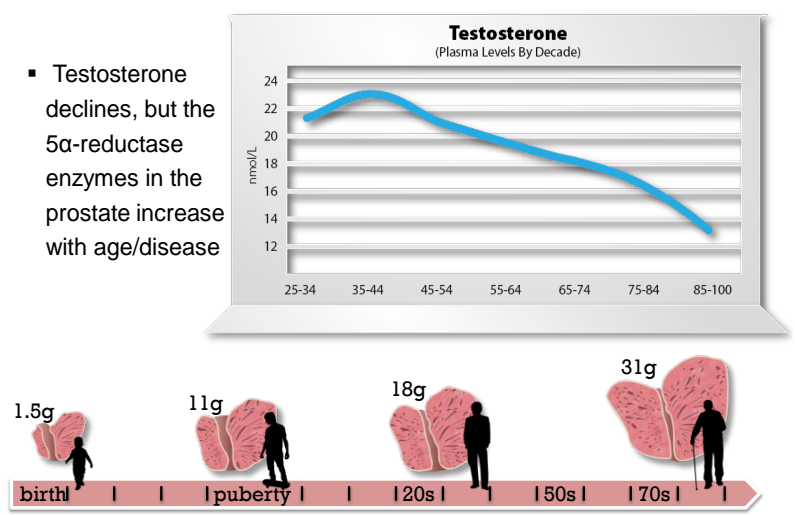

Figure 1. Benign prostatic hyperplasia (BPH) with aging: testosterone levels, intra-prostatic $5 \alpha$-reductase enzyme expression and $5 \alpha$-DHT levels. A cartoon at the bottom of the figure shows prostate enlargement with aging. Plasma testosterone levels were redrawn from [12] with permission (nmol/L on the $y$-axis and years old on the $\mathrm{x}$-axis).

[23]. Correlations between visceral adipose tissue, increased inflammation and estrogen levels in aging or obese men have been reported [24,25].

However, in 2009 Ellem and Risbridger reviewed the dual, but opposing role of estrogens in the prostate [4]. In brief, they reported that: 1) estrogens are essential for normal tissue homeostasis within the prostate, 2) the importance and differential roles of prostatic ER subtypes and most significantly, 3) activation of ER- $\alpha$ leads to aberrant proliferation, inflammation, and the development of premalignant lesions, while, in contrast, the activation of ER- $\beta$ is critical in prostatic stromal-epithelial cell signaling and mediates anti-proliferative effects that balance the proliferative action of androgens on epithelial cells [4]. These data emphasize the importance and complexity of estrogen hormone action within the prostate and highlight the known capacity of estrogens to exert both beneficial and adverse effects via ER- $\beta$ and ER- $\alpha$, respectively [4] (see Figure 2).

Also, the presence of ERR- $\gamma$ appears to play an important role in prostate health. ERR- $\gamma$ is an orphan nuclear receptor whose physiological ligands have yet to be identified. For example, while ERRs are closely related to ERs they do not respond to estrogens [26]. During prostate cancer if ERR- $\gamma$ is present then this is indicative of a favorable prognosis [3], and ERR- $\gamma$ has been shown to slow proliferation in breast cancer cell lines [27]. Moreover, ERR- $\gamma$ suppresses cell proliferation and tumor growth of androgen-sensitive and androgen-insensitive prostate cancer cells [28,29].

Therefore, the importance of estrogens in prostate health cannot be underestimated in light of the beneficial effects of the presence of ER- $\beta$ and ERR- $\gamma$ and their positive actions. The combined influence of androgens via 
ح Activating ER- $\alpha$ can have negative effects in the prostate:

- Proliferation

- Malignancy

- Inflammation

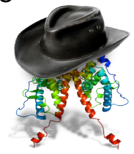

- Activating ER- $\beta$ can have positive effects in the prostate:

- Anti-proliferative

- Anti-carcinogenic

- Anti-inflammatory

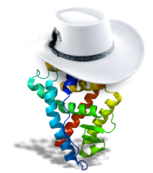

Figure 2. Estrogen receptor alpha (ER- $\alpha$ ) and estrogen receptor beta (ER- $\beta$ ) actions in the prostate. Using a western cowboy theme-the black hat displays negative effects while the white hat displays positive effects. ER subtypes influences redrawn from [4] with permission.

$5 \alpha$-DHT and estrogens via ER and ERR subtypes needs to be considered in future investigations to reveal the interactions of these chemical/hormone signals as significant prognostic factors in modulating BPH.

\section{Current Pharmaceutical Treatments for $\mathrm{BPH}$}

A condensation of a larger body of data will be summarized here. Pharmacological management of BPH include selective and non-selective $\alpha$-blockers (fast acting-hours to days) and $5 \alpha$-reductase inhibitors (5ARI; relatively slow acting-days to months) for men with symptomatic $\mathrm{BPH}[2,7,9,18]$. In some cases, combination therapy of $\alpha$-blockers and 5ARIs are employed due to different and complementary modes of action that potentially maximize treatment response or efficacy [2,9]. International prostate symptom scores (IPSS) improve with both modes of pharmacological treatment. However, the most common side effects of $\alpha$-blockers include: reduced ejaculatory volumes, dizziness, diarrhea, orthostatic hypotension, headache, nasopharyngitis and nasal congestion $[2,9,30]$. For 5ARIs the most common adverse events are sexual dysfunction including, reduced libido, erectile dysfunction and to a lesser extent ejaculation disorders [2,9]. Also gynecomastia can occur in $1 \%-2 \%$ of patients with 5ARIs [2,9]. Finally, the goal of therapy is to reduce or alleviate BPH symptoms, to prevent complications, and to minimize adverse effects of treatments $[9,31,32]$.

\section{Complementary and Alternative Medicine (CAM): Botanicals-Polyphenols, Isoflavones and Equol}

\subsection{Polyphenols}

CAM agents include polyphenols that represent a wide variety of compounds, which are divided into several classes, e.g., hydroxybenzoic acids, hydroxycinnamic acids, anthocyanins, proanthocyanidins, flavonols, fla- vones, flavanols, flavanones, isoflavones, stilbenes, and lignans [33]. An example of a stilbene compound is resveratrol; while in general, isoflavones are soybean-derived products [34] that are found in many food products. Increased research attention directed toward the isoflavonoids in the last 20 - 30 years examined genistein initially that was thought to be responsible for improved prostate health [34-37]. However, since the equol hypothesis was proposed in the late 1990s there has been increased focus on this isoflavonoid molecule [38]. This equol hypothesis suggested that threshold blood equol levels provided increased health benefits for breast, prostate and other diseases/disorders (see Figure 3).

Polyphenols are abundant micronutrients in the human diet, and evidence for their role in the prevention of certain disorders such as cancer and cardiovascular diseases is continuing to emerge [39-43]. Several thousand molecules having a polyphenol structure (ie, several hydroxyl groups on aromatic rings) have been identified in higher plants, and several hundred are found in edible plants $[33,34,39-41]$.

\subsection{Isoflavones}

Soy is the most widely used food product in the world and has been cultivated for over 4000 years where human soy isoflavone consumption has occurred for millennia [44]. Published data by the USDA [45] indicate that isoflavones are components in a wide variety of legumes, prepared foods, spices, teas, and of course, soy food products, including infant formula, tofu, tempeh, cheese, beverages, noodles, sauces, chips and meat substitutes.

The widespread historical exposure to plant isoflavonoids in the diet (by either direct consumption [42,46-54] or secondary consumption via meat and other food products from animals and/or plants) [55-59], is without

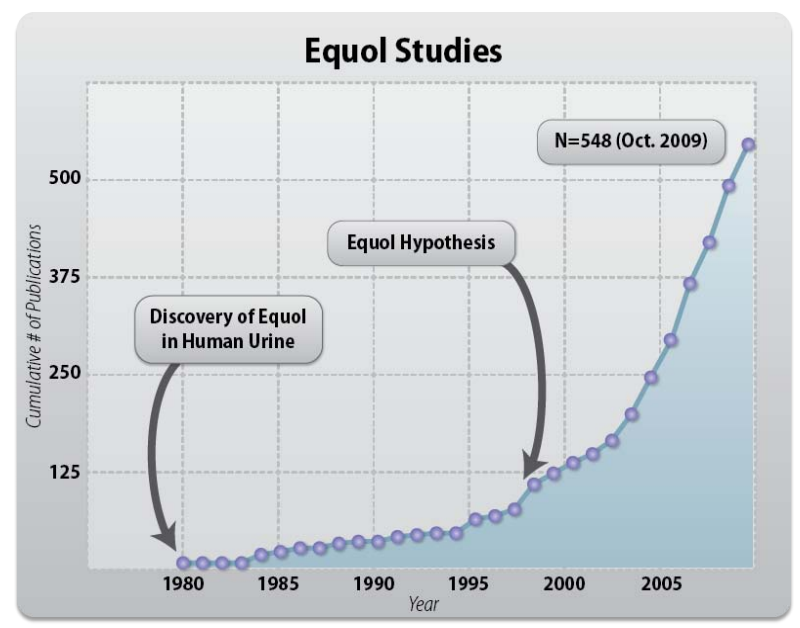

Figure 3. Cumulative number of publications directly investigating equol. Redrawn from [37] with permission. 
adverse human health effects based upon the overall body of available scientific data, which provides compelling evidence of their safety in humans [60].

Also, other data support this notion since isoflavonoid food supplements taken for 2 months had no observable effects on endocrine parameters, testicular volume or semen characteristics at the end of the study and after 4 months of supplementation in men [61]. Furthermore, the developmental status of 1-year old human infants fed soy formula showed normal mental, language and psychomotor development [62] and ultra-sonographic analysis of reproductive organs in 4-month old human infants fed soy formula showed no alterations in reproductive parameters [63]. Finally, the health implications of soy infant formula have been reported [64].

\subsection{Equol}

Equol, [7-hydroxy-3-(4'-hydroxyphenyl)-chroman], was first discovered in the early 1980s in the urine of human adults consuming soy foods [65]. It was shown to be a key metabolite of daidzein, one of the main isoflavones present in soy foods, and it was formed after intestinal hydrolysis of the soy isoflavone glycoside [66]. Equol, therefore, is naturally produced in the intestine, in humans, as a metabolite of soy foods and some individuals are capable of producing higher levels of equol than others [67].

Most animal species exclusively and efficiently produce equol at high levels when fed diets containing soy [46]. For example, all monkeys, rats, mice, chickens, sheep, cattle, pigs, etc. produced exclusively equol from consuming grass, leguminous plants, clovers, alfalfa and soy-containing supplemental food-derived products to increase the protein content of the feed [46].

However, only about $20 \%$ - 30\% of humans living in Western countries produce equol after ingesting soy foods, whereas the frequency of "equol producers" in Asian populations that consume soy foods is typically $50 \%$ - 60\% [46-48,67]. It should be noted that the term "equol-producers" is an arbitrary biomarker set at threshold levels of circulating equol concentrations above 10 $\mathrm{ng} / \mathrm{ml}$ to $20 \mathrm{ng} / \mathrm{ml}$ [68]. The factors for these differences between Western vs Asian populations are unclear [47, 48], but what is apparent is that equol production appears to be a relatively stable phenomenon in humans $[21,38$, 46-48].

It should be noted that equol production in animals is much higher compared to humans. For example, humans that are considered "equol-producers" display levels around 10 to $200 \mathrm{ng} / \mathrm{ml}$ or more, while in all other mammals (except pigs) the levels of equol range between 800 to $2500 \mathrm{ng} / \mathrm{ml}$ or more [21,67-70].

The presence of equol in the environment has been reported in manure, topsoil/subsoil, drainage and lysime- ter water [71]; this is most likely from run-off from fertilized (manure) fields. Equol levels in humans have been reported in: 1) pregnancy [68], 2) infants [68], 3) children and adolescents [72] and adults [38,40,46,47,52,67]. The presence of equol in humans that are "non-equolproducers" usually range from 1 to $5 \mathrm{ng} / \mathrm{ml}$ of equol circulating in their bloodstream. Thus, there are several direct and indirect references of the natural consumption of equol from dietary sources. For example, it is known that equol is contained in the meat and milk products of animals consuming soy-, alfalfa-, or clover-supplemented feeds [33,34,38,46,50,52,54-56]. Also, equol excretion levels correlate positively with the intake of total fat and meat products in humans [50,54].

Further evidence that humans are exposed to equol daily has been reported. For example, equol concentrations in low-soy consuming US populations reflect equol intakes from mammalian (cow) milk sources [73-75] that can be as high as $1.5 \mathrm{mg} / \mathrm{kg}$ in cow's milk [75].

More importantly, equol was recently discovered in plant products. The first study to suggest that equol is present in food products was by Hounsome et al. in 2009 [76]. Subsequent studies by Hounsome et al., in 2010 confirmed the presence of equol in beans, white cabbage and different types of lettuces by Fourier-transform ion cyclotron resonance mass spectrometry [77].

Recent studies by Abiru et al. in 2012 [78] demonstrated that equol is present in other food products. Notably, Abiru et al., measured the equol content of 33 egg yolks where the maximum content was reported to be approximately $130 \mu \mathrm{g} / 100 \mathrm{~g}$. They also examined 21 different fermented soybean foods. In summary, equol was detected in 28 egg different yolks at the maximum content of approximately $43 \mu \mathrm{g} / 100 \mathrm{~g}$. In fermented soybean foods, equol was detected only in stinky tofu. They examined 16 stinky tofu samples purchased during different seasons and the average equol content was $1.39 \mathrm{mg} / 100 \mathrm{~g}$, ranging from 0.34 to $2.68 \mathrm{mg} / 100 \mathrm{~g}$ [78].

Finally, the most recent report (2013) demonstrating that equol is present in stinky tofu in Asian diets was reported by Jou et al. [79]. They showed that $91 \%$ of the 138 stinky tofu dishes contained equol. The mean content per serving (average of 198 grams) was $2.3+2.5 \mathrm{mg}$, the highest being $16.3 \mathrm{mg}$ [79]. Therefore, humans are exposed to this polyphenolic compound from different plant and food sources regardless of age, gender or geographical location with scientific data to support a consumption/exposure record that appears to be safe $[60,64$, $68]$.

\section{Equol: Anti-Oxidant Properties}

Equol is produced in plants and acts as an antioxidant during storage [76]. Notably, the concentration of equol in white cabbage was as high as other isoflavone com- 
pounds and known antioxidants and remains stable for months [76]. Comparative studies examining polyphenolic compounds demonstrated that equol is a superior antioxidant, having greater antioxidant capacity than vitamin C or vitamin E in several in vitro tests [80,81]. In fact, in a more recent study, equol exhibited one of the highest antioxidant activities when three different in vitro assays were used and equol was more effective than the positive controls quercetin and ascorbic acid [82]. Finally, in skin studies equol significantly increased superoxide dismutase (SOD 1) and other antioxidant genes while, at the same time significantly decreased inflammatory genes such as the interleukins and cyclooxygenase $1(\mathrm{COX}-1)[83,84]$.

\section{Equol: Anti-Aging Properties and Mechanisms of Action in BPH}

Equol, unlike its precursor daidzein (or genistein), is unique in having a chiral carbon atom at position C-3 of the furan ring $[21,38,46,68]$. It therefore can occur as 2 distinct isomers as S-equol or R-equol. S-equol has been reported to be the exclusive intestinal metabolite of diadzein in all animals including humans $[21,38,46,68]$ but it has been found in plant products like eggs and stinky tufo $[78,79]$. Notably, the metabolism of R- and S-equol in humans appears to be similar [21,38,85]. Equol is known for its anti-oxidant, anti-inflammatory [72-80] and anti-androgenenic or selective androgen modulator (SAM) activities [86,87].

For example, it was recently demonstrated that both Sequol and R-equol have unique anti-androgenic properties where they both specifically bind $5 \alpha$-DHT with high affinity [86], and thereby prevent DHT from binding the androgen receptor (AR), acting like a SAM. However, to date, there is no evidence that equol blocks the $5 \alpha$-reductase enzymes within the prostate (in animals or men). Equol's SAM activities could be beneficial for prostate health [86], since androgens mediate benign prostatic hyperplasia (BPH) symptoms [1,2].

Equol also has affinity for estrogen related receptor gamma (ERR- $\gamma$ ) and ER- $\beta$ (to increase positive estrogenlike influences in the prostate). Recall, the presence of ERR $-\gamma$ during prostate cancer is indicative of a favorable prognosis, and ERR- $\gamma$ has been shown to slow proliferation in prostate and breast cancer cell lines [27-29]. Using in vitro cultures examining PC-3 cells, equol has been shown to increase the transcriptional activity of ERR- $\gamma$ [88], thereby enhancing the inhibitory actions of ERR- $\gamma$ on neoplastic growth [89]. The concentrations of equol required to stimulate ERR- $\gamma$ are relatively high but not out of physiological range [88] if equol were applied topically or consumed orally.

Finally, it is known that equol (particularly S-equol) has relatively high affinity for ER- $\beta$ where it can act as a selective estrogen receptor modulator (SERM) [21,38,46, $68,86]$. Previous laboratories have shown that isoflavones, like equol, binding to ER- $\beta$ in the prostate can down regulate the AR and thus decrease negative androgen hormone actions [90,91]. Moreover, this may explain how isoflavonoid molecules accumulate in prostate tissue and prostatic fluid after oral supplementation [53,92]. Equol's SERM-like binding to ER- $\beta$ within the prostate has positive implications in decreasing proliferation, inflammation and carcinogenesis $[4,86]$ and down regulating ER- $\alpha$ which has a negative impact on prostate health [4]. In part, equol's powerful anti-oxidant and anti-inflammatory activities may play an important role in this overall mechanism within the prostate which has been demonstrated in human dermal applications [83,84]. A summary of equol's actions in the prostate is shown in Figure 4.

\section{Equol: Treatment of BPH in Men}

One pilot intervention study has been reported in evaluating the effects of a low dose oral equol supplement (6 $\mathrm{mg}$, twice a day with meals) for 4 weeks in a total of 18 men (49 - 60 years old) with moderate or severe BPH [93]. Subjects included in the study gave informed consent, underwent a physical examination, verified their BPH symptoms as measured by the International Prostate Symptom Scores (IPSS) and then were assigned to the moderate or severe BPH groups based upon their total IPSS index. All adverse events were reported. The primary efficacy measure was the IPSS parameters compared baseline to 2 and 4 week IPSS indices. Blood samples were collected at the baseline and 4th week visits that served as secondary efficacy parameters that included testosterone, $5 \alpha$-DHT and general blood chemistries along with cardiac and hepatic function panels. Notably, the safety assessment of R- and S-equol isomer mixtures as a dietary supplement for treating men with BPH has been reported [94].

The results of this study showed a low dose of equol positively improved moderate to severe BPH symptoms according to the IPSS indices. In moderately symptomatic men $(n=10) 5$ out of 7 of the IPSS parameters significantly improved by 4 weeks of equol treatment (see Figure 5). In severely symptomatic men $(n=8)$ all 7 of the IPSS parameters significantly improved with 4 weeks of equol treatment (see Figure 6). There were no significant changes in androgen levels, general blood chemistries or cardiac and hepatic function parameters. However, $5 \alpha$-DHT levels declined by $21 \%$ in severely symptomatic men (from baseline vs. 4 week values).

In examining the evidence that Asian cultures have lower prostate cancer rates compared to Western cultures [34-38,41,46,68,87,93], when data is stratified examining individuals that "produce equol" naturally after soy 
How Equol Works to decrease BPH Symptoms:

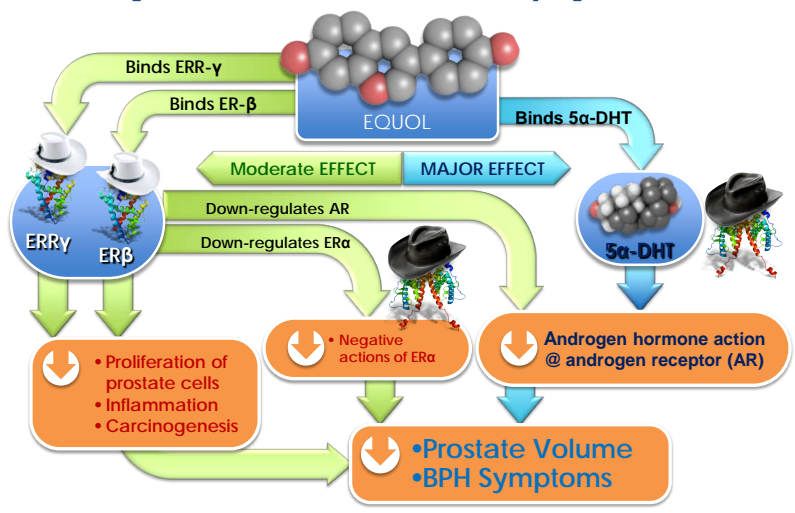

Figure 4. Compounds, receptors and mechanisms of how equol works via various pathways to decrease prostate volume and improve BPH symptoms in men. Estrogen receptor beta (ER- $\beta$ ), estrogen related receptor gamma (ERR$\gamma)$, estrogen receptor alpha (ER- $\alpha$ ), $5 \alpha$-dihydrotestosterone (5 $\alpha$-DHT), androgen receptor (AR) and white hats represent positive influences while black hats represent negative influences. Redrawn from [92] with permission.

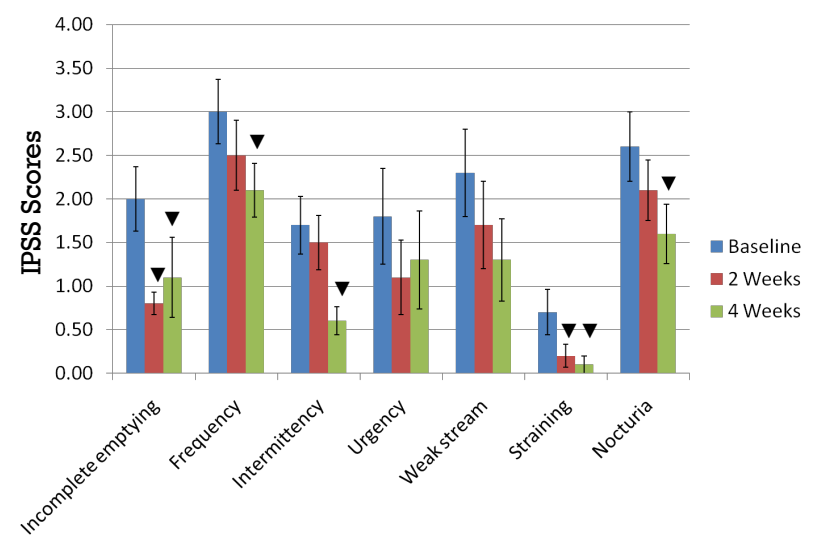

Figure 5. International prostate symptom score (IPSS) values in moderately symptomatic men $(n=10)$ treated with equol. $\nabla=$ Significant reduction in IPSS values (within a given parameter) at 2 weeks and/or 4 weeks treatment compared to baseline. Redrawn from [92] with permission.

consumption suggest that lower cancer rates are due to the beneficial influence of this isoflavonoid molecule [95]. Moreover, while equol has been shown to have positive benefits in human prostate health, there is evidence that R-equol, rather than S-equol is responsible for the in vivo chemoprotective properties of equol [96]. However, regardless of the actual mechanism by which equol enhances prostate health it is known from other clinical investigations that isoflavone supplementation that increased the production of serum equol in "equol-producers" resulted in a decline in serum $5 \alpha$-DHT levels in men by approximately $18 \%$ versus before supplementation values [97]. These results are similar to the pilot intervention study above where a $21 \%$ reduction in $5 \alpha$ -

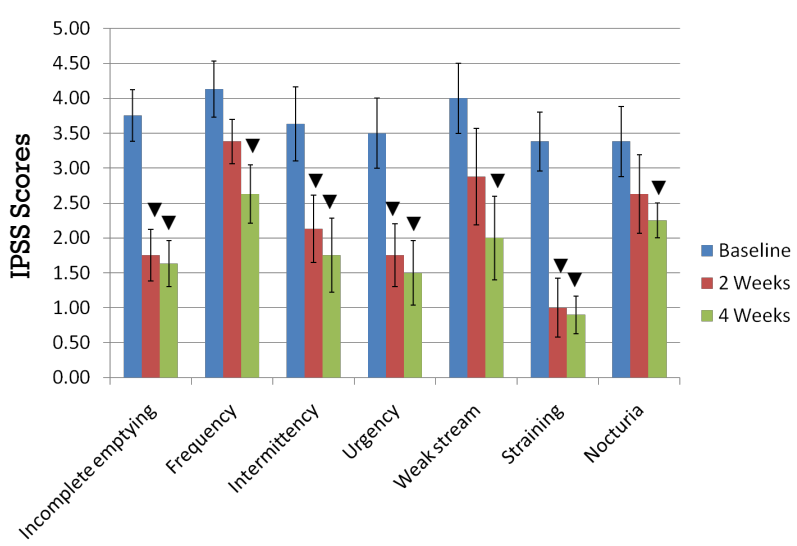

Figure 6. International prostate symptom score (IPSS) values in severely symptomatic men $(n=8)$ treated with equol. $\boldsymbol{\nabla}=$ Significant reduction in IPSS values (within a given parameter) at 2 weeks and/or 4 weeks treatment compared to baseline. Redrawn from [92] with permission.

DHT was observed in the severely symptomatic group with oral equol treatment with corresponding significant improvements in prostate symptoms via IPSS values. The reasons moderately symptomatic men did not display any alterations in $5 \alpha$-DHT levels during the intervention are unknown, but the significant positive influence of the equol treatment on IPSS indices over the course of the study may be due to the other mechanisms of actions outlined above.

\section{Equol: Anti-Cancer and Other Disorders}

A recent review by Douglas et al. (2013) summarized current human and animal data that provide evidence for several anti-cancer properties of isoflavones in reference to breast cancer [98]. In this regard, one of the first reports on equol as an anti-cancer agent for breast cancer examined case-control studies where there was a substantial reduction in cancer risk with high equol excretion [99]. Later studies by Magee et al. found that equol (particularly R-equol) possessed chemoprotective properties in breast and prostate cells in vitro [96,100]. In fact, equol has been reported to enhance tamoxifen's antitumor activity by induction of caspase-mediated apoptosis in MCF-7 breast cancer cells [101]. Also, there is evidence that being an "equol-producer" has clinical benefit in protection against breast cancer [38,102]. As a final point, equol has been reported to be a DNA methytransferase- 1 inhibitor that may be an epigenetic therapy for cancer [103].

In reference to prostate cancer, as reported by Akaza et al., the ability to be an "equol producer" or the administration of equol itself is closely related to a lower incidence of prostate cancer [95]. Equol is also known to inhibit invasion in prostate cancer cells due to a downregulation of matrix metalloproteinases (MMPs) [104], 
which corresponds with human dermal studies that displayed similar findings of equol inhibiting the gene expression of MMPs [83,84].

Finally, Richardson and Simpkins have reported that equol could have beneficial effects in delaying the onset and decreasing the severity of symptoms in Friedreich's ataxia patients by an antioxidant mechanism unrelated to binding estrogen receptor subtypes [105]. Thus, there are several reported studies that suggest equol has chemoprotective properties from both in vitro and clinical studies.

\section{Conclusion}

$\mathrm{BPH}$ is the pathological cellular progression of glandular proliferation associated with aging affecting millions of men usually over the age of fifty in the US and worldwide. The primary changes in BPH are mediated by $5 \alpha-$ DHT. However, recent evidence suggests that estrogen hormone actions via estrogen receptor subtypes (ERR- $\gamma$ and ER- $\beta$ ) also play important roles in BPH. Current pharmaceutical options for BPH like selective and nonselective $\alpha$-blockers and $5 \alpha$-reductase inhibitors have advantages, limitations and adverse effects. CAM treatments for BPH include botanicals such as polyphenols and isoflavones. Equol is a polyphenolic/isoflavonoid molecule derived from intestinal metabolism, dairy and dietary plant sources. Equol has potent anti-oxidant, antiinflammatory, anti-androgenic and positive estrogenic properties (via ERR- $\gamma$ and ER- $\beta$ ) to decrease prostatic irritation and potentially neoplastic growth. The clinical efficacy of equol to significantly decrease BPH symptoms is presented. The beneficial clinical efficacy of equol observed may be due to the multiple positive biological actions that are not present in current pharmaceutical treatments. Finally, equol appears to have chemo-protective effects and cyto-protective effects in Friedreich's ataxia.

\section{Acknowledgements}

This study was supported, in part, by a BYU TTO/LS grant \#19221560.

\section{REFERENCES}

[1] J. T. Wei, E. A. Calhoun and S. J. Jacobsen, "Benign Prostatic Hyperplasia,” In: M. S. Litwin and C. S. Saigal, Eds., Urologic Disease in America, US Department of Health and Human Services, Public Health Service, National Institutes of Health, National Institute of Diabetes and Digestive and Kidney Diseases, US Government Publishing Office, Washington DC, NIH Publication No. 04-5512, 2004, pp. 43-69.

[2] A. Gravas and M. Oelke, "Current Status of $5 \alpha$-Reductase Inhibitors in the Management of Lower Urinary Tract
Symptoms and BPH,” World Journal of Urology, Vol. 28, No. 1, 2010, pp. 9-15.

http://dx.doi.org/10.1007/s00345-009-0493-y

[3] T. Fujimura, S. Takahashi, T. Urano, N. Ijichi, K Ikeda, J. Kumagai, et al., "Differential Expression of EstrogenRelated Receptors $\beta$ and $\gamma(\operatorname{ERR} \beta$ and ERR $\gamma)$ and Their Clinical Significance in Human Prostate Cancer," Cancer Science, Vol. 101, No. 3, 2010, pp. 646-651. http://dx.doi.org/10.1111/j.1349-7006.2009.01451.x

[4] S. J. Ellem and G. P. Risbridger, "The Dual, Opposing Role of Estrogens in the Prostate," Annals New York Academy of Science, Vol. 1155, 2009, pp. 174-186. http://dx.doi.org/10.1111/j.1749-6632.2009.04360.x

[5] S. J. Berry, D. S. Coffey, P. C. Walsh and L. L. Ewing, "The Development of Human Benign Prostatic Hyperplasia with Age,” Journal of Urology, Vol. 132, No. 3, 1984, pp. 474-479.

[6] J. T. Wei, E. Calhoun and S. J. Jacobsen, "Urologic Diseases in America Project: Benign Prostatic Hyperplasia," Journal of Urology, Vol. 179, No. 5, 2008, pp. S75-S80. http://dx.doi.org/10.1016/j.juro.2008.03.141

[7] J. Sausville and M. Naslund, "Benign Prostatic Hyperplasia and Prostate Cancer: An Overview for Primary Care Physicians,” International Journal of Clinical Practice, Vol. 64, No. 13, 2010, pp. 174-1745. http://dx.doi.org/10.1111/j.1742-1241.2010.02534.x

[8] K, Kijvikai, "Digital Rectal Examination, Serum Prostatic Specific Antigen or Transrectal Ultrasonography: The Best Tool to Guide the Treatment of Men with Benign Prostatic Hyperplasia," Current Opinion in Urology, Vol. 19, No. 1, 2009, pp. 44-48. http://dx.doi.org/10.1097/MOU.0b013e32831743d0

[9] M. Emberton, E. B. Cornel, P. F. Bassi, R. O. Fourcade, J. M. F. Gómez and R. Castro, "Benign Prostatic Hyperplasia as a Progressive Disease: A Guide to the Risk Factors and Options for Medical Management,” International Journal of Clinical Practice, Vol. 62, No. 7, 2008, pp. 1076-1086. http://dx.doi.org/10.1111/j.1742-1241.2008.0 1785.x

[10] W. D. Tilley, M. Marcelli and M. J. Phaul, "Recent Studies of the Androgen Receptor-New Insights into Old Questions,” Molecular Cellular Endocrinology, Vol. 68, No. 2-3, 1990, pp. C7-C10. http://dx.doi.org/10.1016/0303-7207(90)90178-B

[11] K. P. DeJésus-Tran, P.-L. Côté, L. Cantin, J. B. Blanchet, F. Labrie and R. Breton, "Comparison of Crystal Structures of Human Androgen Receptor Ligand-Binding Domain Complexed with Various Agonists Reveal Molecular Determinants Responsible for Binding Affinity,” Protein Science, Vol. 15, No. 5, 2006, pp. 987-999. http://dx.doi.org/10.1110/ps.051905906

[12] D. Simon, K. Nahoul and M. A. Charles, "Sex Hormones, Aging, Ethnicity and Insulin Sensitivity in Men: An Overview of the TELECOM Study,” In: A. Vermeulen and B. J. Oddens, Eds., Androgens and the Aging Male, Parthenon Publishing, New York, 1996, pp. 85-102.

[13] D. Schulthesiss, S. Machtens and U. Jonas, “Testosterone Therapy in the Aging Male: What about the Prostate?” Andrologia, Vol. 36, No. 6, 2004, pp. 355-365. 
http://dx.doi.org/10.1111/j.1439-0272.2004.00630.x

[14] J. M. Kaufman and A. Vermeulen, "The Decline of Androgen Levels in Elderly Men and Its Clinical and Therapeutic Implications,” Endocrine Reviews, Vol. 26, No. 6, 2005, pp. 833-876. http://dx.doi.org/10.1210/er.2004-0013

[15] G. R. Cunningham and S. M. Toma, "Why Is Androgen Replacement in Males Controversial?” Journal Clinical Endocrinology Metabolism, Vol. 96, No. 1, 2011, pp. 3852. http://dx.doi.org/10.1210/jc.2010-0266

[16] B. B. Yeap, H. Alfonso, S. A. P. Chubb, D. J. Handelsman, G. J. Hankey, J. Golledge, et al., "Lower Plasma Testosterone or Dihydrotestosterone, but No Estradiol, Is Associated with Symptoms of Intermittent Claudication in Older Men,” Clinical Endocrinology, Vol. 79, No. 1, 2013, pp. 725-732.

[17] Y.-S. Zhu and J. L. Imperato-McGinely, " $5 \alpha$-Reductase Isozymes and Androgen Actions in the prostate," Annals of the New York Academy of Sciences, Vol. 1155, 2009, pp. 43-56. http://dx.doi.org/10.1111/j.1749-6632.2009.04115.x

[18] L. N. Thomas, R. C. Douglas, C. B. Lazier, C. K. L. Too, R. S. Rittmaster and D. J. Tindall, "Type 1 and Type 2 $5 \alpha$-Reductase Expression in the Development and Progression of Prostate Cancer,” European Urology, Vol. 53, No. 1, 2008, pp. 244-252.

http://dx.doi.org/10.1016/j.eururo.2007.10.052

[19] G. Androle, N. Bruchovsky, L. W. K, Chung, A. M. Matsumoto, R. Rittimaster, C. Roehrborn, et al., "Dihydrotestosterone and the Prostate: The Scientific Rationale for $5 \alpha$-Reductase Inhibitors in the Treatment of Benign Prostatic Hyperplasia,” Journal Urology, Vol. 172, No. 4, 2004, pp. 1399-1408.

http://dx.doi.org/10.1097/01.ju.0000139539.94828.29

[20] C. L. Smith, “Estrogens, Overview,” In: E. Knobil and J. D. Neill, Eds., Encyclopedia of Reproduction, Vol. 2, Academic Press, New York, 1999, pp. 119-126.

[21] K. D. R. Setchell, C. Clerici, E. D. Lephart, S. J. Cole, C. Heenan, D. Castellani, et al., "S-Equol, a Potent Ligand for Estrogen Receptor $\beta$, Is the Exclusive Enantiomeric Form of the Soy Isoflavone Metabolite Produced by $\mathrm{Hu}-$ man Intestinal Bacterial Flora,” American Journal Clinical Nutrition, Vol. 81, No. 5, 2005, pp. 1072-1079.

[22] D. L. Hemsell, J. M. Grodin, P. K, Siiteri and P. C. McDonald, "Plasma Precursors of Estrogen II. Correlation of the Extent of Plasma Androstenedione to Estrone with Age,” Journal Clinical Endocrinology Metabolism, Vol. 38, No. 3, 1974, pp. 476-479. http://dx.doi.org/10.1210/jcem-38-3-476

[23] S. E. Bulun and E. R. Simpson, "Competitive RT-PCR Analysis Indicates Levels of Aromatase Cytochrome P450 transcripts in Adipose Tissue of Buttocks, Thighs and Abdomen of Women Increase with Advancing Age," Journal Clinical Endocrinology Metabolism, Vol. 78, No. 2, 1994, pp. 428-432. http://dx.doi.org/10.1210/jc.78.2.428

[24] S. M. Haffner, R. A. Valdez, M. P. Stern and M. S. Katz, "Obesity, Body-Fat Distribution and Sex-Hormones in Men,” International Journal Obesity, Vol. 17, No. 11,
1993, pp. 643-649.

[25] A. Gautier, F. Bonnet, S. Dubois, C. Massart, C. Grosheny, A. Bachelot, C. Aube, B. Balkau and P.-H. Ducluzeau, "Associations between Visceral Adipose Tissue, Inflammation and Sex Steroid Concentrations in Men," Clinical Endocrinology, Vol. 78, No. 3, 2013, pp. 373378.

[26] V. Giguère, “To ERR in the Estrogen Pathway,” Trends Endocrinology Metabolism, Vol. 13, No. 5, 2002, pp. 220-225. http://dx.doi.org/10.1016/S1043-2760(02)00592 $-1$

[27] E. A. Ariazi, G. M. Clark and J. E. Mertz, "EstrogenRelated Receptor $\alpha$ and Estrogen-Related Receptor $\beta$ Associate with Unfavorable and Favorable Biomarkers, Respectively, in Human Breast Cancer," Cancer Research, Vol. 62, No. 22, 2002, pp. 6510-6518.

[28] S. Yu, X. Wang, C. F. Ng, S. Chen and F. L. Chan, "EER-Gamma Suppresses Cell Proliferation and Tumor Growth of Androgen-Sensitive and Androgen-Insensitive Prostate Cancer Cells and Its Implication as a Therapeutic Target for Prostate Cancer," Cancer Research, Vol. 67, No. 10, 2007, pp. 4909-4914. http://dx.doi.org/10.1158/0008-5472.CAN-06-3855

[29] S. Yu, Y. C. Wong, M. T. Ling, C. F. Ng, S. Chen and F. L. Chen, "Orphan Nuclear Receptor Estrogen-Related Receptor-Gamma Suppresses in Vitro and in Vivo Growth of Prostate Cancer Cells via p21WAF1/CIP1 Induction and as a Potential Therapeutic Target in Prostate Cancer," Oncogene, Vol. 27, No. 23, pp. 3313-3328.

http://dx.doi.org/10.1038/sj.onc.1210986

[30] M. Emberton, N. Zinner, M. C. Michel, M. Gittelman, M.-K. Chung and S. Madersbacher, "Managing the Progression of Lower Urinary Tract Symptoms/Benign Prostatic Hyperplasia: Therapeutic Options for the Man at Risk,” British Journal of Urology International, Vol. 100, No. 2, 2007, pp. 249-253.

http://dx.doi.org/10.1111/j.1464-410X.2007.07056.x

[31] M. J. Barry and C. G. Roehrborn, "Benign Prostatic Hyperplasia,” British Medical Journal, Vol. 323, No. 7320, 2001, pp. 1042-1046. http://dx.doi.org/10.1136/bmj.323.7320.1042

[32] K. T. McVary, C. G. Roehrborn, A. Avins, M. J. Barry, R. C. Bruskewitz, R. F. Donnell, et al., "Guideline on the Management of Benign Prostatic Hyperplasia (BPH),” American Urological Association Education and Research, Inc., Baltimore, 2010, pp. 1-134.

[33] C. Manach, G. Williamson, C. Morand, A. Scalbert and C. Rémésy, "Bioavailability and Bioefficacy of Polyphenols in Humans, I. Review of 97 Bioavailability Studies,” American Journal Clinical Nutrition, Vol. 81, Supplement 1, 2005, pp. 230S-242S.

[34] H. Adlercreutz and W. Mazur, "Phyto-Estrogens and Western Diseases,” Annuals of Medicine, Vol. 29, No. 2, 1997, pp. 95-120. http://dx.doi.org/10.3109/07853899709113696

[35] C. Brőssner, K. Petritsch, K. Fink, M. Auprich, S. Madersbacher and H. Adlercreutz, et al., " Phytoestrogen Tissue Levels in Benign Prostatic Hyperplasia and Prostate Cancer and Their Association with Prostate Diseases,” 
Urology, Vol. 64, No. 4, 2004, pp. 707-711. http://dx.doi.org/10.1016/j.urology.2004.04.046

[36] V. U. Kumar, "Phyto-Oestrogens and Prostatic Growth," National Medical Journal of India, Vol. 17, No. 1, 2004, pp. 22-26.

[37] K. Griffiths, L. Denis, A. Turkes and S. Morton, "Phytoestrogens and Diseases of the Prostate Gland," Bailliere's Clinical Endocrinology and Metabolism, Vol. 12, No. 4, 1998, pp. 625-647. http://dx.doi.org/10.1016/S0950-351X(98)80008-6

[38] K. D. Setchell and C. Clerici, "Equol: History, Chemistry, and Formation," Journal of Nutrition, Vol. 140, No. 7, 2010, pp. 1355S-1362S. http://dx.doi.org/10.3945/jn.109.119776

[39] C. Manach, A. Scalbert, C. Morand, C. Rémésy and L. Jime'nez, "Polyphenols: Food Sources and Bioavaiability," American Journal Clinical Nutrition, Vol. 79, No. 5, 2004, pp. 727-747.

[40] H. Adlercreutz, M. Yaghoob and K. Hőckerstedt, "Diet and Breast Cancer,” Acta Oncologica, Vol. 31, No. 2, 1992, pp. 175-181. http://dx.doi.org/10.3109/02841869209088899

[41] H. Adlercreutz, "Phytoestrogen: Epidemiology and a Possible Role in Cancer Protection," Environmental Health Perspectives, Vol. 103, Supplement 7, 1995, pp. 103-112.

[42] K. D. Setchell, S. P. Borriello, P. Hulme, D. N. Kirk and M. Axelson, "Nonsteroidal Estrogens of Dietary Origin: Possible Roles in Hormone-Dependent Disease," American Journal of Clinical Nutrition, Vol. 40, No. 3, 1984, pp. 569-578.

[43] J. M. Smoliga, J. A. Baur and H. A. Hausenblas, "Resveratrol and Health-A Comprehensive Review of Human Clinical Trials," Molecular Nutrition \& Food Research, Vol. 55, No. 8, 2011, pp. 1129-1141. http://dx.doi.org/10.1002/mnfr.201100143

[44] K. F. Kiple and K. C. Ornelas, “Soybean,” In: The Cambridge World History of Food, Vol. 1, Cambridge University Press, New York, 2000, pp. 422-427.

[45] USDA, "USDA - Iowa State University Database on the Isoflavone Content of Foods, Release 1.4,” Agricultural Research Service, Beltsville Human Nutrition Research Center, Nutrient Data Laboratory, Beltsville, 2007.

[46] K. D. R. Setchell, N. M. Brown and E. Lydeking-Olson, "The Clinical Importance of the Metabolite Equol-A Clue to the Effectiveness of Soy and Its Isoflavones,” Journal of Nutrition, Vol. 132, No. 12, 2002, pp. 3577-3584.

[47] C. Atkinson, C. L. Frankenfeld and J. W. Lampe, “Gut Bacterial Metabolism of the Soy Isoflavone Daidzein: Exploring the Relevance to Human Health,” Experimental Biology \& Medicine, Vol. 230, No. 3, 2005, pp. 155170.

[48] I. R. Rowland, T. A. Sanders, H. Adlercreutz and E. A. Bowey, "Inter-Individual Variation in Metabolism of Soy Isoflavones and Lignans: Influence of Habitual Diet on Equol Production by the Gut Flora," Nutriton and Cancer, Vol. 36, No. 1, 2000, pp. 27-32. http://dx.doi.org/10.1207/S15327914NC3601_5

[49] J.-P. Yuan, J.-H. Wang and X. Liu, "Metabolism of Die- tary Soy Isoflavones to Equol by Human Intestinal Microflora-Implications for Health,” Molecular Nutrition \& Food Research, Vol. 51, No. 7, 2007, pp. 765-781. http://dx.doi.org/10.1002/mnfr.200600262

[50] K. Ozasa, M. Nakao, Y. Watanabe, K. Hayaski, T. Miki, K. Mikami, et al., "Association of Serum Phytoestrogen Concentration and Dietary Habits in a Sample Set of the JACC Study,” Journal of Epidemiology, Vol. 15, Supplement 2, 2005, pp. S196-S202. http://dx.doi.org/10.2188/jea.15.S196

[51] J. W. Lampe, "Isoflavonoid and Lignan Phytoestrogens as Dietary Biomarkers,” Journal of Nutrition, Vol. 133, Suppl. 3, 2003, pp. 956S-964S.

[52] H. Adlercreutz, H. Honjo, A. Higashi, T. Fotsis, E. Hamalainen, T. Hasegawa, et al., "Urinary Excretion of Lignans and Isoflavonoids Phytoestrogens in Japanese Men and Women Consuming a Traditional Japanese Diet," American Journal of Clinical Nutrition, Vol. 54, No. 6, 1991, pp. 1093-1100.

[53] T. E. Hedlund, P. D. Maroni, P. G. Ferucci, R. Dayton, S. Barnes, K, Jones, et al., "Long-Term Dietary Habits Affect Soy Isoflavone Metabolism and Accumulation in Prostatic Fluid in Causasian Men,” Journal Nutrition, Vol. 135, No. 6, 2005, pp. 1400-1406.

[54] L. Valentin-Blasini, M. A. Sadowski, D. Walden, L. Caltabiano, L. L. Needhan and D. B. Barr, "Urinary Phytoestrogen Concentrations in the U.S. Population (1999-2000)," Journal Exposure Analysis and Environmental Epidemiology, Vol. 15, No. 3, 2005, pp. 509-523.

http://dx.doi.org/10.1038/sj.jea.7500429

[55] A. Hoikkälä, S. Mustonen, I. Saastamoinen, T. Jokela, J. Taponen, H. Saloniemi, et al., "High Levels of Equol in Organic Skimmed Finnish Cow Milk,” Molecular Nutrition \& Food Research, Vol. 51. No. 7, 2007, pp. 782-786. http://dx.doi.org/10.1002/mnfr.200600222

[56] C. Bannwart, H. Adlercreutz, T. Fotsis, K, Wähälä, T. Hare and G. Barrow, "Identification of Isoflavonic Phytoestrogens and Lignans in Urine of Human and in Cow Milk by GC/MS," Advances in Mass Spectrometry, Vol. 10, No. 4, 1986, pp. 661-622.

[57] R. A. King, M. M. Mano and R. J. Head, “Assessment of Isoflavonoid Concentrations in Australian Bovine Milk Samples,” Journal of Dairy Research, Vol. 65, No. 3, 1998, pp. 479-489. http://dx.doi.org/10.1017/S0022029998002891

[58] T. J. O. Lundh, H. I. Petersson and K. A. Martinsson, "Comparative Levels of Free and Conjugated Plant Estrogens in Blood Plasma of Sheep and Cattle Fed Ostrogenic Silage,” Journal of Agriculture and Food Chemistry, Vol. 38, No. 7, 1990, pp. 1530-1534. http://dx.doi.org/10.1021/jf00097a022

[59] R. H. Common and L. Ainsworth, "Identification of Equol in the Urine of the Domestic Fowl," Biochimica et Biophysica Acta, Vol. 53, No. 2, 1961, pp. 403-404. http://dx.doi.org/10.1016/0006-3002(61)90452-8

[60] J. M. Hamilton-Reeves, G. Vazque, S. J. Duval, W. R. Phipps, M. S. Kurzer and M. J. Messian, "Clinical Studies Show no Effects of Soy Protein or Isoflavones on Reproductive Hormones in Men: Results of a Meta-Analysis," 
Fertility and Sterility, Vol. 94, No. 3, 2010, pp. 997-1007. http://dx.doi.org/10.1016/j.fertnstert.2009.04.038

[61] J. H. Mitchell, E. Cawood, D. Kinniburgh, A. Provan, A. R. Collins and D. S. Irvine, "Effect of a Phytoestrogen Food Supplement on Reproductive Health in Normal Males," Clinical Science (London), Vol. 100, No. 6, 2001, pp. 613-618. http://dx.doi.org/10.1042/CS20000212

[62] A. Andres, M. A. Cleves, J. B. Bellando, R. T. Pivik, P. H. Casey and T. M. Badger, "Developmental Status of 1Year-Old Infants Fed Breast Milk, Cow’s Milk Formula, or Soy Formula,” Pediatrics, Vol. 129, No. 6, 2012, pp. 1134-1140. http://dx.doi.org/10.1542/peds.2011-3121

[63] J. M. Gilchrist, M. B. Moore, A. Andres, J. A. Estroff and T. M. Badger, "Ultrasonographic Patterns of Reproductive Organs in Infants Fed Soy Formula: Comparisons to Infants Fed Breast Milk and Milk Formula," Journal of Pediatrics, Vol. 156, No. 2, 2010, pp. 215-220. http://dx.doi.org/10.1016/j.jpeds.2009.08.043

[64] T. M. Badger, J. M. Gilchrist, R. T. Pivik, A. Andres, K. Shandar, J.-R. Chen and M. J. Ronis, "The Health Implications of Soy Infant Formula,” American Journal of Nutrition, Vol. 89, No. 5, 2009, pp. 1668S-1672S. http://dx.doi.org/10.3945/ajcn.2009.26736U

[65] M. Axelson, D. N. Kirk, R. D. Farrant, G. Cooley, A. M. Lawson and K. D. R. Setchell, "The Identification of Equol [7-Hydroxy-3-(4'-Hydroxy Phenyl) Chroman] in Human Urine,” Biochemical Journal, Vol. 201, No. 2, 1982, pp. 353-357.

[66] K. D. R. Setchell, N. M. Brown, L. Zimmer-Nechemias, W. T. Brashear, B. E. Wolf, A. S. Kirschner, et al., "Evidence for Lack of Absorption of Soy Isoflavone Glycosides in Humans, Supporting the Crucial Role of Intestinal Metabolism for Bioavailability,” American Journal of Clinical Nutrition, Vol. 76, No. 2, 2002, pp. 447-453.

[67] K. D. R. Setchell and S. J. Cole, "Method of Defining Equol-Producer Status and Its Frequency among Vegetarians,” Journal of Nutrition, Vol. 136, No. 8, 2006, pp. 2188-2193.

[68] E. D. Lephart, "Isoflavones and prenatal Exposure to Equol, Chapter 29,” In: V. R. Preedy, Ed., Isoflavones: Chemistry, Analysis, Function and Effects, The Royal Society of Chemistry, Thomas Graham House, Cambridge, England, 2013, pp. 480-499.

[69] E. D. Lephart, J. P. Porter, D. W. Hedges, T. D. Lund and K. D. R. Setchell, "Phytoestrogens: Implications in Neurovascular Research," Current Neurovascular Research, Vol. 1, No. 5, 2004, pp. 455-464. http://dx.doi.org/10.2174/1567202043361974

[70] L. W. Gu, S. E. House, R. L. Prior, N. Fang, M. J. J. Ronis, T. B. Clarkson, et al., "Metabolic Phenotypes of Isoflavones Differ among Female Rats, Pigs, Monkeys, and Women,” Journal of Nutrition, Vol. 136, No. 5, 2006, pp. 1215-1221.

[71] C. C. Hoerger, F. E. Wettstein, H. J. Bachmann, K. Hungerbübler and T. D. Bucheli, "Occurrence and Mass Balance of Isoflavones on an Experimental Grassland Field,” Environmental Science \& Technology, Vol. 45, No. 16, 2011, pp. 6752-6760. http://dx.doi.org/10.1021/es200567b
[72] G. H. Degen, M. Balaszkewicz, L. J. Shi, A. E. Buyken and T. Remer, "Urinary Isoflavone Phytoestrogens in German Children and Adolescents- A Longitudinal Examination in the DONALD Cohort," Molecular Nutrition Food Research, Vol. 55, No. 3, 2011, pp. 359-367. http://dx.doi.org/10.1002/mnfr.201000325

[73] E. A. Mustonen, M. Tuori, I. Saastamoinen, J. Taponen, K. Wähälä, H. Saloniemi and A. Vanhatalo, "Equol in Milk of Dairy Cows Is Derived from Forage Legumes such as Red Clover,” British Journal of Nutrition, Vol. 102, No. 11, 2009, pp. 1552-1556. http://dx.doi.org/10.1017/S0007114509990857

[74] C. L. Frankenfeld, "Dairy Consumption Is a Significant Correlate of Urinary Equol Concentration in Representative Sample of US Adults," American Journal of Clinical Nutrition, Vol. 93, No. 5, 2011, pp. 1109-1116. http://dx.doi.org/10.3945/ajcn.111.011825

[75] A. Höjer, S. Alder, S. Purup, J. Hansen-Møller, K. Martinsson, H. Steinshamn and A.-M. Gustavsson, "Effects of Feeding Dairy Cows Different-Legume-Grass Silages on Milk Phytoestrogen Concentration," Journal of Dairy Science, Vol. 95, No. 8, pp. 4526-4540. http://dx.doi.org/10.3168/jds.2011-5226

[76] N. Hounsome, B. Hounsome, D. Tomos and G. EdwardsJones, "Changes in Antioxidant Compounds in White Cabbage during Winter Storage,” Postharvest Biology \& Technology, Vol. 52, No. 2, 2009, pp.173-179. http://dx.doi.org/10.1016/j.postharvbio.2008.11.004

[77] N. Hounsome, B. Grail, A. D. Tomos, B. Hounsome and Edwards-Jones, "High-Throughput Anti-Oxidant Profiling in Vegetables by Fourier-Transform Ion Cyclotron Resonance Mass Spectrometry," Functional Plant Science and Biotechnology, Vol. 4, No. 1, 2010, pp. 1-10.

[78] Y. Abiru, M. Kumenura, T. Ueno, S. Uchiyama and K. Masaki, "Discovery of an S-Equol Rich Food Stinky Tofu, a Traditional Fermented Soy Product in Taiwan," International Journal of Food Science and Nutrition, Vol. 63, No. 8, 2012, pp. 964-970. http://dx.doi.org/10.3109/09637486.2012.687369

[79] H. J. Jou, P. J. Tsai, J. H. Tu and W. H. Wu, "Stinky Tofu as a Rich Source of Bioavailable S-Equol in Asian Diets," Journal of Functional Foods, Vol. 5, No. 2, 2013, pp. 651-659. http://dx.doi.org/10.1016/j.jff.2013.01.006

[80] J. H. Mitchell, P. T. Gardner, D. B. McPhail, P. C. Morrice, A. R. Collins and G. C. Duthie, "Antioxidant Efficacy of Phytoestrogens in Chemical and Biological Model Systems," Archives of Biochemistry and Biophysics, Vol. 360, No. 1, 1998, pp. 142-148. http://dx.doi.org/10.1006/abbi.1998.0951

[81] A. Arora, M. G. Nair and G. M. Strasburg, “Antioxidant Activities of Isoflavones and Their Biological Metabolites in a Liposomal Dystem," Archives of Biochemistry and Biophysics, Vol. 356, No. 2, 1998, pp. 133-141. http://dx.doi.org/10.1006/abbi.1998.0783

[82] C. E. Rüfer and S. E. Kulling, “Antioxidant Activity of Isoflavones and Their Major Metabolites Using Different in Vitro Assays," Journal of Agriculture and Food Chemistry, Vol. 54, No. 8, 2006, pp. 2926-2931. http://dx.doi.org/10.1021/jf053112o 
[83] R. Gopaul, H. E. Knaggs and E. D. Lephart, "Biochemical Investigation and Gene Analysis of Equol: A Plant and Soy-Derived Isoflavonoid with Anti-Aging and Antioxidant Properties with Potential Human Skin Applications,” BioFactors, Vol. 38, No. 1, 2012, pp. 44-52. http://dx.doi.org/10.1002/biof.191

[84] E. D. Lephart, "Protective Effects of Equol and Their Polyphenolic Isomers against Dermal Aging: Mircoarray/Protein Evidence with Clinical Implications and Unique Delivery into Human Skin,” Pharmaceutical Biology, Vol. 51, No. 11, 2013, pp. 1393-1400. http://dx.doi.org/10.3109/13880209.2013.793720

[85] K. D. R. Setchell, X. Zhao, P. Jha, J. E. Heubi and N. M. Brown, "The Pharmacokinetic Behavior of the Soy Isoflavone Metabolite S-Equol and Its Diastereoismer R-Equol in Healthy Adults Determined by Using Stable-IsotopeLabeled Tracers," American Journal of Clinical Nutrition, Vol. 90, No. 4, 2009, pp. 1029-1037. http://dx.doi.org/10.3945/ajcn.2009.27981

[86] T. D. Lund, D. J. Munson, M. E. Hadley, K. D. R. Setchell, E. D. Lephart and R. J. Handa, "Equol Is a Novel Anti-Androgen that Inhibits Prostate Growth and Hormone Feedback," Biology Reproduction, Vol. 70, No. 4, 2004, pp. 1188-1195. http://dx.doi.org/10.1095/biolreprod.103.023713

[87] T. D. Lund, L. Blake, L. Bu, A. N. Hamaker and E. D. Lephart, "Equol an Isoflavonoid: Potential for Improved Prostate Health, in Vitro and in Vivo Evidence," Reproductive Biology and Endocrinology, Vol. 9, 2011, p. 4.

[88] J. Hirvonen, A. M. Rajalin, G. Wohlfahrt, H. Adlercreutz, K. Wähälä and P. Aarnisalo, "Transcriptional Activity of Estrogen-Related Receptor Gamma (ERRgamma) Is Stimulated by the Phytoestrogen Equol," Journal of Steriod Biochemistry and Molecular Biology, Vol. 123, No. 1-2, 2011, pp. 46-57. http://dx.doi.org/10.1016/j.jsbmb.2010.11.001

[89] T. Fujimura, S. Takahashi, T. Urano, et al., "Differential Expression of Estrogen-Related Receptors Beta and Gamma (ERR $\beta$ and ERR $\gamma$ ) and Their Clinical Significance in Human Prostate Cancer," Cancer Science, Vol. 101, No. 3, 2010, pp. 646-651. http://dx.doi.org/10.1111/j.1349-7006.2009.01451.x

[90] J. M. Hamilton-Reeves, S. A. Rebello, W. Thomas, J. W. Slaton and M. S. Kurzer, "Isoflavone-Rich Soy Protein Isolate Suppresses Androgen Receptor Expression without Altering Estrogen Receptor- $\beta$ Expression or Serum Hormonal Profiles in Men at High Risk of Prostate Cancer,” Journal of Nutrition, Vol. 137, No. 7, 2007, pp. 1769-1775.

[91] T. D. Lund, D. J. Munson, H. Adlercreutz, R. J. Handa and E. D. Lephart, “Androgen Receptor Expression in the Rat Prostate Is Down Regulated by Dietary Phytoestrogens,” Reproductive Biology and Endocrinology, Vol. 2, 2004, p. 5.

[92] C. D. Gardner, B. Oelrich, J. P. Liu, D. Feldmen, A. A. Franke and J. D. Brooks, “ Prostatic Soy Isoflavone Concentrations Exceed Serum Levels after Dietary Supplementation," Prostate, Vol. 69, No. 7, 2009, pp. 719-726. http://dx.doi.org/10.1002/pros.20922
[93] E. D. Lephart, "Severe and Moderate BPH Symptoms in Mid-Aged Men Improved with Isoflavonoid-Equol Treatment: Pilot Intervention Study,” Open Journal of Urology, Vol. 3, No. 1, 2013, pp. 21-27.

[94] E. D. Lephart, "Safety Assessment of R,S-Equol as a Dietary Supplement for Benign Prostatic Hyperplasia," Proceedings Society of Toxicology, Phoenix, 2014, pbn. 1585, p. 244.

[95] H. Akaza, N. Miyanaga, N. Takashima, S. Naito, S. Hirao, Y. Tsukamoto, T. Fujloka, et al., "Comparisons of Percent Equol Producers between Prostate Cancer Patients and Controls: Case-Controlled Studies of Isoflavones in Japanese, Korean and American Residents,” Japanese Journal of Clinical Oncology, Vol. 34, No. 2, 2004, pp. 86-89. http://dx.doi.org/10.1093/jico/hyh015

[96] P. J. Magee, M. Raschke, C. Steiner, J. G. Duffin, B. L. Pool-Zobel, T. Jokela, et al., "Equol: A Comparison of the Effects of the Racemic Compound with that of the $\mathrm{Pu}$ rified S-Enantiomer on the Growth, Invasion, and DNA Integrity of Breast and Prostate Cells in Vitro," Nutrition and Cancer, Vol. 54, No. 2, 2006, pp. 232-242. http://dx.doi.org/10.1207/s15327914nc5402_10

[97] M. Tanaka, K. Fujimoto, Y. Chihara, K. Torimoto, T. Yoneda and N. Tanaka, "Isoflavone Supplements Stimulated the Production of Serum Equol and Decreased the Serum Dihydrotestosterone Levels in Healthy Male Volunteers," Prostate Cancer and Prostatic Disease, Vol. 12, No. 3, 2009, pp. 247-252.

http://dx.doi.org/10.1038/pcan.2009.10

[98] C. C. Douglas, S. A. Johnson and B. H. Arjmandi, "Soy and Its Isoflavones: The Truth behind the Science in Breast Cancer," Anti-Cancer Agents in Medicinal Chemistry, Vol. 13, No. 8, 2013, pp. 1178-1187. http://dx.doi.org/10.2174/18715206113139990320

[99] D. Ingram, K, Sanders, M. Kolybaba and D. Lopez, "CaseControl Study of Phyto-Oestrogens and Breast Cancer," Lancet, Vol. 350, No. 9083, 1997, pp. 990-994. http://dx.doi.org/10.1016/S0140-6736(97)01339-1

[100] P. J. Magee, P. Allsopp, A. Samaletdin and I. R. Rowland, "Daidzein, R-equol and S-equol Inhibit the Invasion of MDA-MB-231 Breast Cancer Cells Potentially via the Down-Regulation of Matrix Metalloproteinase-2," European Journal of Nutrition, Epub Ahead of Print, 2013.

[101] C. Charalambous, C. A. Pitta and A. I. Constantinou, "Equol Enhances Tamoxifen's Anti-Tumor Activity by Induction of Caspase-Mediated Apoptosis in MCF-7 Breast Cancer Cells,” BMC Cancer, Vol. 13, 2013, p. 238.

[102] M. Minatoya, G. Kutomi, S. Asakura, S. Otokozawa, Y. Sugiyama, Y. Nagata, et al., "Equol, Adiponectin, Insulin Levels and Risk of Breast Cancer,” Asian Pacific Journal of Cancer Prevention, Vol. 14, No. 4, 2013, pp. 21912199. http://dx.doi.org/10.7314/APJCP.2013.14.4.2191

[103] V. Singh, P. Sharma and N. Capulash, "DNA Methyltransferase-1 Inhibitors as Epigenetic Therapy for Cancer," Current Cancer Drug Targets, Vol. 13, No. 4, 2013, pp. 379-399. http://dx.doi.org/10.2174/156800961131399900 $\underline{77}$

[104] W. Zheng, Y. Zhang, D. Ma, Y. Shi, C. Liu and P. Wang, 
“Equol Inhibits Invasion in Prostate Cancer DU145 Cells Possibly via Down-Regulation of Matrix Metalloproteinase-9, Matrix Metalloproteinase-2 and Urokinase-Type Plasmiogen Activator by Antioxidant Activity," Journal of Clinical Biochemical Nutrition, Vol. 51, No. 1, 2012, pp. 61-67. http://dx.doi.org/10.3164/jcbn.11-54
[105] T. E. Richardson and J. W. Simpkins, "R- and S-Equol Have Equivalent Cytoprotective Effects in Friedreich's Ataxia," BMC Pharmacology and Toxicology, Vol. 13, 2012, p. 12. 